Article

\title{
Gold-Iron Oxide Catalyst for CO Oxidation: Effect of Support Structure
}

\author{
Hui-Zhen Cui ${ }^{1}$, Yu Guo ${ }^{1}$, Xu Wang ${ }^{2}$, Chun-Jiang Jia ${ }^{1, *}$ and Rui $\mathrm{Si}^{2, *}$ \\ 1 Key Laboratory for Colloid and Interface Chemistry, Key Laboratory of Special Aggregated Materials, \\ School of Chemistry and Chemical Engineering, Shandong University, Jinan 250100, China; \\ cuihz0129@163.com (H.-Z.C.); guoyu1115@163.com (Y.G.) \\ 2 Key Laboratory of Interfacial Physics and Technology, Shanghai Synchrotron Radiation Facility, Shanghai \\ Institute of Applied Physics, Chinese Academy of Sciences, Shanghai 201204, China; wangxu@sinap.ac.cn \\ * $\quad$ Correspondence: jiacj@sdu.edu.cn (C.-J.J.); sirui@sinap.ac.cn (R.S.); Tel.: +86-531-8836-3683 (C.-J.J.); \\ +86-21-3393-2079 (R.S.)
}

Academic Editor: Michalis Konsolakis

Received: 26 November 2015; Accepted: 26 January 2016; Published: 7 March 2016

\begin{abstract}
Gold-iron oxide $\left(\mathrm{Au} / \mathrm{FeO}_{x}\right)$ is one of the highly active catalysts for $\mathrm{CO}$ oxidation, and is also a typical system for the study of the chemistry of gold catalysis. In this work, two different types of iron oxide supports, i.e., hydroxylated (Fe_OH) and dehydrated iron oxide (Fe_O), have been used for the deposition of gold via a deposition-precipitation (DP) method. The structure of iron oxide has been tuned by either selecting precipitated $\mathrm{pH}$ of 6.7-11.2 for $\mathrm{Fe}$ _OH or changing calcination temperature of from 200 to $600{ }^{\circ} \mathrm{C}$ for Fe_O. Then, $1 \mathrm{wt}$. \% Au catalysts on these iron oxide supports were measured for low-temperature $\mathrm{CO}$ oxidation reaction. Both fresh and used samples have been characterized by multiple techniques including transmission electron microscopy (TEM) and high-resolution TEM (HRTEM), X-ray diffraction (XRD), X-ray photoelectron spectroscopy (XPS), $\mathrm{X}$-ray absorption near edge structure (XANES) and temperature-programmed reduction by hydrogen ( $\mathrm{H}_{2}$-TPR). It has been demonstrated that the surface properties of the iron oxide support, as well as the metal-support interaction, plays crucial roles on the performance of $\mathrm{Au} / \mathrm{FeO}$ catalysts in CO oxidation.
\end{abstract}

Keywords: gold catalyst; iron oxide; CO oxidation; support effect; metal-support interaction

\section{Introduction}

Since the 1990s, nanosized gold interacting with oxide supports have been reported to be active for diverse redox reactions, among those low temperature oxidation of carbon monoxide is the most studied [1-3]. Such unique catalytic properties were found to be strongly dependent on electronic structure and local coordination environment of $\mathrm{Au}$ atoms. During the last two decades, different reducible metal oxides such as titanium oxide $\left(\mathrm{TiO}_{2}\right)$ [4], cerium oxide $\left(\mathrm{CeO}_{x}\right)[5,6]$ and iron oxide $\left(\mathrm{FeO}_{x}\right)$ [7] have been proven to be active supports for deposition of gold. Although a full mechanism of this catalytic process still needs to be established, careful studies on strong metal-support interaction by the aid of various characterization techniques may provide further mechanistic insight [8-11]. For instance, Hutchings group reported that the delayered Au structure that was determined by high-angle annular dark-field scanning transmission electron microscopy (HAADF-STEM) characterization plays crucial roles in the $\mathrm{CO}$ oxidation reaction [8].

As one of the important functional materials, iron oxide $\left(\mathrm{FeO}_{x}\right)$ has been extensively investigated in heterogeneous catalysis for its potential applications in $\mathrm{CO}$ oxidation [12,13], water-gas shift [14-17] and preferential oxidation of $\mathrm{CO}$ reaction [18-20]. The general $\mathrm{FeO}_{x}$ supports include two different types: hydrated (Fe_OH), such as goethite or lepidocrocite $\mathrm{FeOOH}$, and dehydrated (Fe_O), such as 
hematite $\alpha-\mathrm{Fe}_{2} \mathrm{O}_{3}$, maghemite $\gamma-\mathrm{Fe}_{2} \mathrm{O}_{3}$ or magnetite $\mathrm{Fe}_{3} \mathrm{O}_{4}$. These complexities in composition and crystal periodicity provide rich structural models for gold deposition. On the other hand, various synthetic approaches, including so-gel method [21,22], hydrothermal method $[23,24]$ and precipitation method $[10,25]$, have been applied to control the size and shape of the iron oxide itself, aiming to delicately tune the interaction between metal and oxide matrix, as well as the local structure of active metals. Among them, the precipitation method is simple and easy to operate. It can easily control the synthesis parameters and achieve larger surface area. Furthermore, the precipitating conditions of $\mathrm{Fe}^{2+}$ or $\mathrm{Fe}^{3+}$ precursor has been identified as one of the key factors governing the structure and texture of the $\mathrm{FeO}_{x}$ products. Focusing on synthesis, the final $\mathrm{pH}$ value of the stock solution and the calcination temperature of the as-dried materials, which have not been widely studied so far [26,27], could be very important parameters for the preparation of high-quality iron oxide support.

Different techniques, including X-ray diffraction (XRD) [25], X-ray absorption fine structure (XAFS) [16], X-ray photoelectron spectroscopy (XPS) [16] and transmission electron microscopy (TEM) [28], have been used to characterize both bulk and surface structure of gold-iron oxide catalysts and further study the related active site for the low-temperature CO oxidation. Due to the complicated crystal and local structures in bulk and microdomain, the combination of multiple characterization skills, rather than a single means, is extremely important to obtain the real structural information.

Therefore, in the present work, we try to broadly explore the relationship between the nature of the oxide matrix and the catalytic reactivity of $\mathrm{Au} / \mathrm{FeO}_{x}$ via deposition-precipitation with two series of iron oxides, namely hydrated (Fe_OH) and dehydrated (Fe_O) supports, to fully investigate the importance of preparation parameters such as precipitating $\mathrm{pH}$ values and calcination temperature in synthesis of $\mathrm{FeO}_{x}$, and to deeply study the "structure-activity" relationship in $\mathrm{Au} / \mathrm{FeO}_{x}$ system for the low-temperature $\mathrm{CO}$ oxidation reaction.

\section{Results and Discussion}

\subsection{Structure and Texture of Gold-Iron Oxide Catalyst}

The inductively coupled plasma atomic emission spectroscopy (ICP-AES) characterization was conducted to identify the gold loadings in both $\mathrm{Fe} \_\mathrm{OH}$ and $\mathrm{Fe} \_\mathrm{O}$ supports. Table 1 shows that the experimental bulk $\mathrm{Au}$ concentrations $\left(\mathrm{Au}_{b u l k}\right)$ in all the measured samples are in good agreement with the target value $(0.54$ at. \%), revealing no gold loss in DP synthesis. The BET specific surface areas $\left(\mathrm{S}_{\mathrm{BET}}\right)$ of the fresh $\mathrm{Au} / \mathrm{FeO}_{x}$ catalysts are summarized in Table 1. Since the hydrated iron oxide (Fe_OH) supports were uncalcined, the corresponding $\mathrm{S}_{\mathrm{BET}}$ values for $\mathrm{Au} / \mathrm{Fe} \_\mathrm{OH}\left(151-212 \mathrm{~m}^{2} / \mathrm{g}\right)$ are distinctly higher than those for $\mathrm{Au} / \mathrm{Fe} \_\mathrm{O}\left(27-136 \mathrm{~m}^{2} / \mathrm{g}\right)$, in which the dehydrated iron oxide (Fe_O) supports were calcined at different temperatures in the range of $200-600^{\circ} \mathrm{C}$. For $\mathrm{Au} / \mathrm{Fe} \_\mathrm{OH}$ series, the $\mathrm{S}_{\mathrm{BET}}$ number decreases with the increase of precipitating $\mathrm{pH}$ value of Fe_OH from 6.7 to 11.2, possibly indicating better crystallinity of iron oxide support with more hydroxyls used in preparation. For $\mathrm{Au} / \mathrm{Fe} \_\mathrm{O}$ series, the $\mathrm{S}_{\mathrm{BET}}$ number decreases with the increase of calcination temperature of $\mathrm{Fe} \_\mathrm{O}$ from 200 to $600{ }^{\circ} \mathrm{C}$, giving hints on the elimination of surface $\mathrm{OH}$ groups during the heat-treatment process. Thus, the textural properties of iron oxide supports, as well as the final $\mathrm{Au} / \mathrm{FeO}_{x}$ catalysts, are strongly dependent by the synthetic parameters used in experiments.

XRD was carried out to determine the crystal structure of the fresh $\mathrm{Au} / \mathrm{FeO}_{x}$ catalysts. Figure 1a displays an amorphous phase for $\mathrm{Au} / \mathrm{Fe} \_\mathrm{OH} \_6.7$ and $\mathrm{Au} / \mathrm{Fe} \_\mathrm{OH} \_8.2$, or partially crystallized structure of $\mathrm{Au} / \mathrm{Fe} \_\mathrm{OH} \_9.7$ and $\mathrm{Au} / \mathrm{Fe} \_\mathrm{OH} \_11.2$ with further increasing on the applied pH value. The corresponding crystal phase is hematite $\alpha-\mathrm{Fe}_{2} \mathrm{O}_{3}$ (JCPDS card No: 2-919), consistent with previous reports on gold-iron oxide catalysts [28]. Comparable to the above characterization results on surface area, the precipitating $\mathrm{pH}$ significantly affected the crystallinity of $\mathrm{Fe} \_\mathrm{OH}$ support, and further modified the structural properties of $\mathrm{Au} / \mathrm{Fe} \_\mathrm{OH}$ catalyst. Figure $1 \mathrm{~b}$ exhibits that the crystallinity of $\mathrm{Au} / \mathrm{Fe} \_\mathrm{O}$ was clearly enhanced by applying higher calcination temperature on Fe_O support, while the crystal phase was kept as hematite $\alpha-\mathrm{Fe}_{2} \mathrm{O}_{3}$. We also noticed that all measured samples were fully 
crystallized if the iron oxide support was calcined above $200{ }^{\circ} \mathrm{C}$, which is in good agreement with the previous findings [28]. However, no Au diffraction peaks can be identified in Figure 1 due to the presence of gold in the form of amorphous or the low Au concentrations ( 0.54 at. \%).

Table 1. Bulk $\mathrm{Au}$ concentrations $\left(\mathrm{Au}_{b u l k}\right)$, surface $\mathrm{Au}$ concentrations $\left(\mathrm{Au}_{\text {surf }}\right)$, BET (Brunner-Emmet-Teller) specific surface areas $\left(\mathrm{S}_{\mathrm{BET}}\right)$ and $\mathrm{Au}$ 4f XPS peak positions of gold-iron oxide catalysts.

\begin{tabular}{|c|c|c|c|c|}
\hline Sample & $\mathrm{Au}_{b u l k}$ (at. \%) $^{a}$ & $\mathbf{A u}_{\text {surf }}(\text { at. } \%)^{b}$ & $\mathbf{S}_{\mathrm{BET}}\left(\mathbf{m}^{2} \cdot \mathbf{g}^{-1}\right)^{c}$ & $\mathrm{Au} 4 \mathrm{f}(\mathrm{eV})$ \\
\hline $\mathrm{Au} / \mathrm{Fe} \_\mathrm{OH} \_11.2$ & 0.53 & $0.67(1.20)$ & 151 & 84.55 (84.2), 88.15 (87.9) \\
\hline $\mathrm{Au} / \mathrm{Fe} \_\mathrm{OH} \_9.7$ & 0.54 & - & 198 & - \\
\hline $\mathrm{Au} / \mathrm{Fe} \_\mathrm{OH} \_8.2$ & 0.52 & - & 203 & - \\
\hline $\mathrm{Au} / \mathrm{Fe} \_\mathrm{OH} \_6.7$ & 0.53 & $0.55(0.42)$ & 212 & $84.6(84.0), 88.15(87.7)$ \\
\hline $\mathrm{Au} / \mathrm{Fe} \_\mathrm{O} \_600$ & 0.53 & - & 27 & - \\
\hline $\mathrm{Au} / \mathrm{Fe}$ _O_500 & 0.52 & - & 42 & - \\
\hline $\mathrm{Au} / \mathrm{Fe} \_\mathrm{O} \_400$ & 0.53 & - & 58 & - \\
\hline $\mathrm{Au} / \mathrm{Fe}$ _O_300 & 0.52 & $0.68(0.74)$ & 97 & $84.7(84.15), 88.4(87.85)$ \\
\hline $\mathrm{Au} / \mathrm{Fe}$ _O_200 & 0.53 & $0.63(0.54)$ & 136 & $84.35(84.2), 88.05(87.85)$ \\
\hline
\end{tabular}

${ }^{a}$ Determined by ICP-AES; ${ }^{b}$ Determined by XPS. The numbers in brackets are for the used catalysts; ${ }^{c}$ Calculated from the adsorption branch.
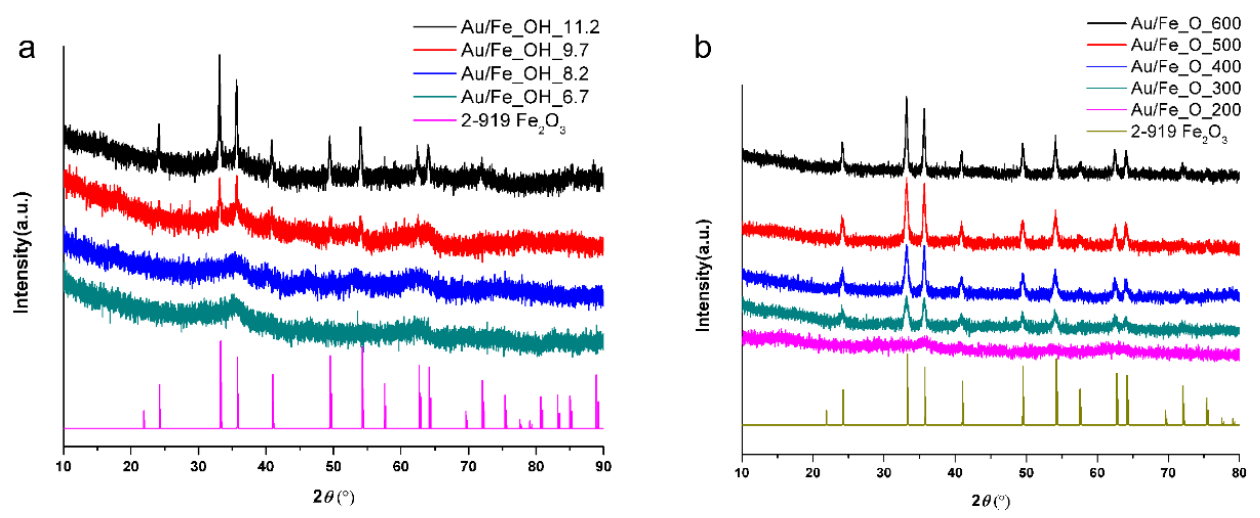

Figure 1. XRD patterns of fresh $\mathrm{Au} / \mathrm{FeO}_{x}$ catalysts: (a) $\mathrm{Au} / \mathrm{Fe} \_\mathrm{OH}$ and (b) $\mathrm{Au} / \mathrm{Fe} \_\mathrm{O}$.

TEM was conducted to identify the morphology of fresh $\mathrm{Au} / \mathrm{FeO}_{x}$ catalysts, i.e., the size and shape for gold or iron oxide support. No Au nanoparticles have been observed in all the pictures in Figure 2, confirming that gold was still in the form of atoms or ultra-fine $(<2 \mathrm{~nm})$ clusters for the as-dried $\left(60^{\circ} \mathrm{C}\right)$ samples. This was also in good agreement with our previous results on $\mathrm{Au} / \mathrm{FeO}_{x}$ [28]. For the iron oxide support, it can be seen from the TEM images that small-size $(<5 \mathrm{~nm})$ aggregates were observed for amorphous Fe_OH, Au/Fe_OH_6.7 (Figure 2d), Au/Fe_OH_8.2 (Figure 2c) and Au/Fe_O_200 (Figure 2i); big-size particles $(10-50 \mathrm{~nm}$ ) were identified for fully crystallized Au/Fe_O_600 (Figure 2e), $\mathrm{Au} / \mathrm{Fe}$ _O_500 (Figure 2f), Au/Fe_O_400 (Figure 2g) and Au/Fe_O_300 (Figure 2h); and a mixture of small aggregates and big particles was confirmed for partially crystallized Au/Fe_OH_11.2 (Figure 2a) and Au/Fe_OH_9.7 (Figure 2b). These results were well consistent with the related XRD data.

For the used catalysts, we found from Figure 3 that the morphologies of iron oxide supports were maintained for all the tested samples under the mild reaction conditions (up to $300{ }^{\circ} \mathrm{C}$ and less than $1.5 \mathrm{~h}$ ). Gold particles with size of $c a .2 \mathrm{~nm}$ can be identified for gold on the fully crystallized Fe_O supports (Figure 3e-h). However, gold species cannot be distinguished clearly in Au/Fe_OH catalysts due to the amorphous state of $\mathrm{Fe} \_\mathrm{OH}$ particles, so the structure of gold in $\mathrm{Au} / \mathrm{Fe} \_\mathrm{OH}$ is to be investigated using other techniques such as XPS and XAFS (these will be mentioned later). 
HRTEM was used to determine the crystallinity of iron oxide supports. Figure 4a-d exhibits the highly crystallized nature of $\mathrm{Fe} \_\mathrm{O}$ for $\mathrm{Au} / \mathrm{Fe} \_\mathrm{O} \_300$ and $\mathrm{Au} / \mathrm{Fe} \_\mathrm{O} \_200$, either fresh or used in $\mathrm{CO}$ oxidation.
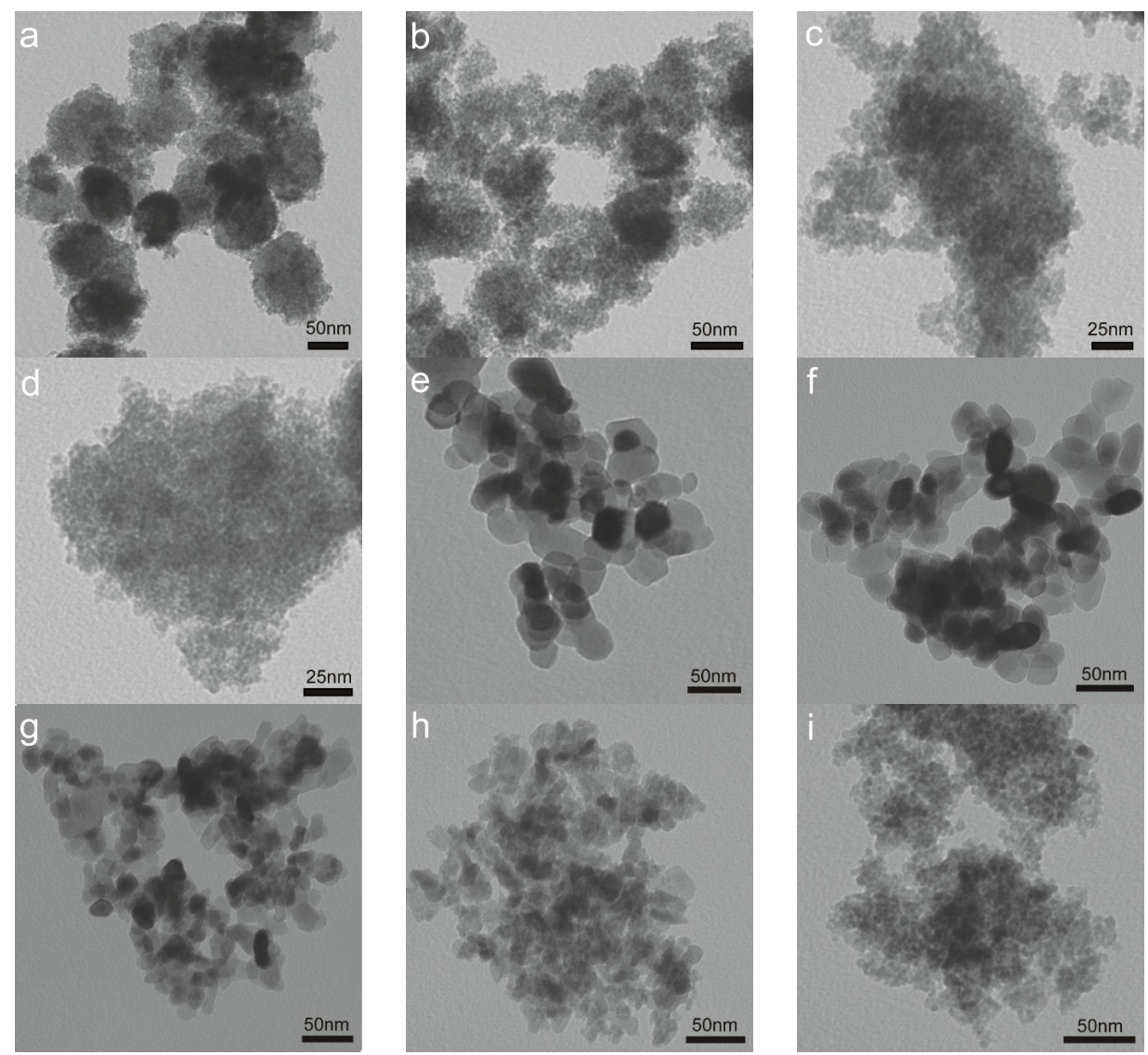

Figure 2. TEM images of fresh $\mathrm{Au} / \mathrm{FeO}_{x}$ catalysts: (a) $\mathrm{Au} / \mathrm{Fe} \_\mathrm{OH} \_11.2 ;$ (b) $\mathrm{Au} / \mathrm{Fe} \_\mathrm{OH} \_9.7$;

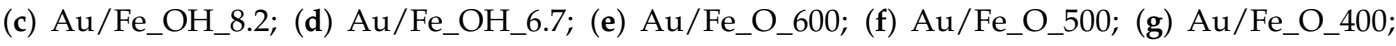
(h) $\mathrm{Au} / \mathrm{Fe} \_\mathrm{O} \_300 ;$ and (i) $\mathrm{Au} / \mathrm{Fe} \_\mathrm{OH} \_200$.
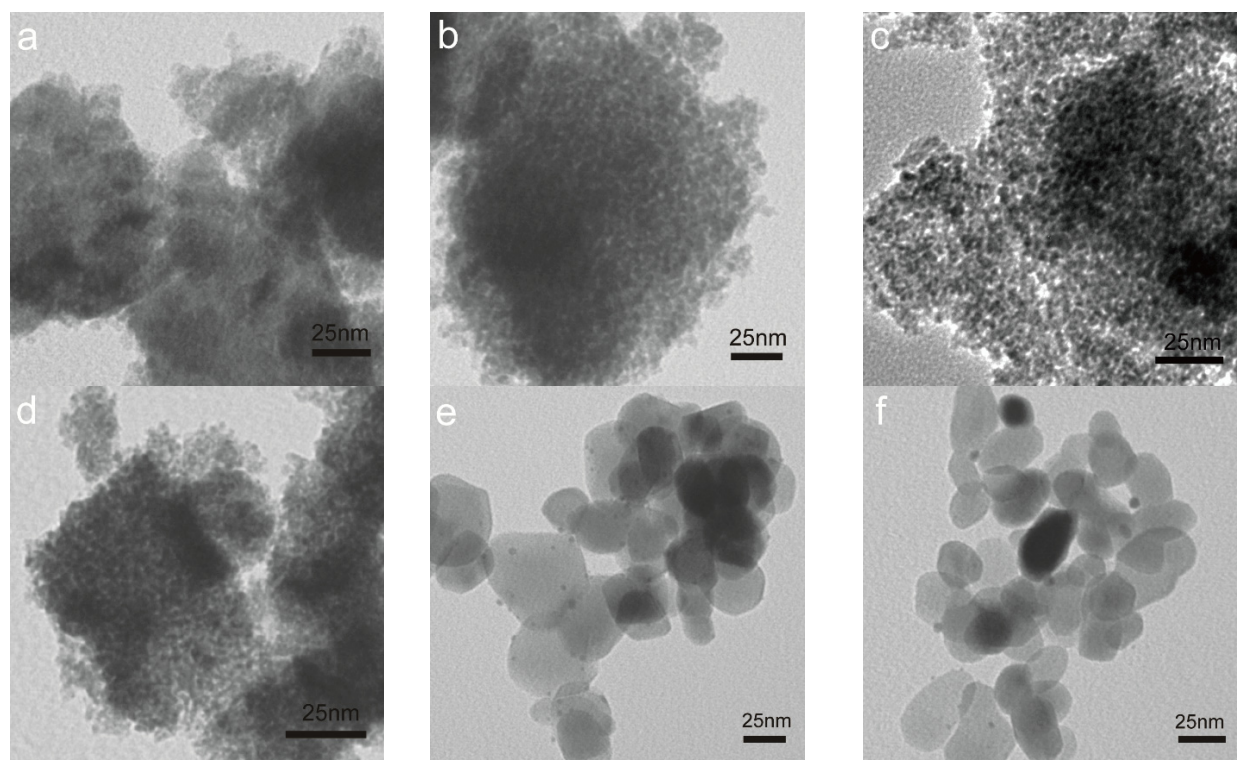

Figure 3. Cont. 

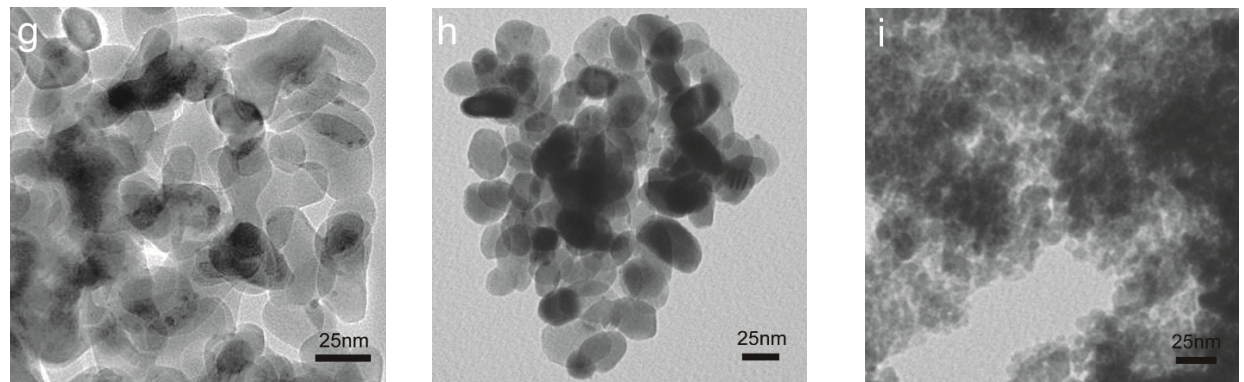

Figure 3. TEM images of used $\mathrm{Au} / \mathrm{FeO}_{x}$ catalysts: (a) $\mathrm{Au} / \mathrm{Fe} \_\mathrm{OH} \_11.2$; (b) $\mathrm{Au} / \mathrm{Fe} \_\mathrm{OH} \_9.7$; (c) $\mathrm{Au} / \mathrm{Fe} \_\mathrm{OH} \_8.2 ;$ (d) $\mathrm{Au} / \mathrm{Fe} \_\mathrm{OH} \_6.7 ;\left(\right.$ e) $\mathrm{Au} / \mathrm{Fe} \_\mathrm{O} \_600 ;$ (f) $\mathrm{Au} / \mathrm{Fe} \_\mathrm{O} \_500 ;(\mathrm{g}) \mathrm{Au} / \mathrm{Fe} \_\mathrm{O} \_400$; (h) $\mathrm{Au} / \mathrm{Fe} \_\mathrm{O} \_300 ;$ and (i) $\mathrm{Au} / \mathrm{Fe} \_\mathrm{O} \_200$.
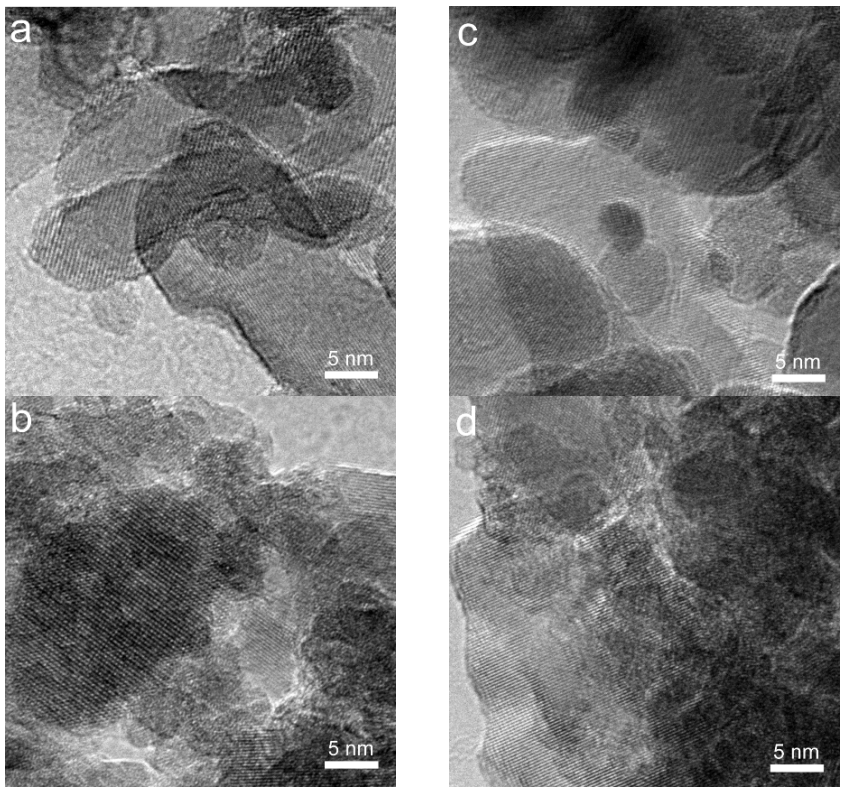

Figure 4. HRTEM images (a-d) of $\mathrm{Au} / \mathrm{FeO}_{x}$ catalysts: (a) $\mathrm{Au} / \mathrm{Fe} \_\mathrm{O} \_300$, fresh; (b) Au/Fe_O_200, fresh; (c) Au/Fe_O_300, used; and (d) Au/Fe_O_200 used.

\subsection{Catalytic Performance and Reducibility of Gold-Iron Oxide Catalyst}

The catalytic performance of the $\mathrm{Au} / \mathrm{FeO}_{x}$ catalysts was evaluated for the low-temperature $\mathrm{CO}$ oxidation. The transient profiles in Figure 5a reveal a lower "light off" temperature or a higher activity for gold on hydrated iron oxide support synthesized with an increasing $\mathrm{pH}$ value. The $90 \% \mathrm{CO}$ conversion temperature $\left(T_{90}\right)$ was $62{ }^{\circ} \mathrm{C}$ for $\mathrm{Au} / \mathrm{Fe} \_\mathrm{OH} \_6.7$, while it was $25^{\circ} \mathrm{C}$ for $\mathrm{Au} / \mathrm{Fe} \_\mathrm{OH} \_11.2$. The corresponding "steady-state" experiments in Figure $5 \mathrm{c}$ confirmed that the long-term CO conversions at $30{ }^{\circ} \mathrm{C}$ after $6 \mathrm{~h}$ were stabilized at $53 \%, 41 \%, 20 \%$ and $11 \%$ for the $\mathrm{Fe} \_\mathrm{OH}$ precipitating $\mathrm{pH}$ value of 11.2, 9.7, 8.2 and 6.7, respectively. All of the above demonstrate the following sequence of catalytic reactivity on $\mathrm{Au} / \mathrm{Fe} \_\mathrm{OH}$ for the $\mathrm{CO}$ oxidation reaction: $\mathrm{Au} / \mathrm{Fe} \_\mathrm{OH} \_11.2>$ $\mathrm{Au} / \mathrm{Fe} \_\mathrm{OH} \_9.7>\mathrm{Au} / \mathrm{Fe} \_\mathrm{OH} \_8.2>\mathrm{Au} / \mathrm{Fe} \_\mathrm{OH} \_6.7$. In our previous work, $\mathrm{pH}=8.2$ was applied to prepare $\mathrm{Fe} \_\mathrm{OH}$ [28], which was based on reported synthesis [8,12]. It is noticed that the long-term stability of $\mathrm{Au} / \mathrm{Fe} \_\mathrm{OH} \_8.2$ in final $\mathrm{CO}$ conversion was lower than that reported previously [28]. We repeated the catalytic tests at $30^{\circ} \mathrm{C}$ several times and found that the deactivation behavior varied with the testing periods. Thus, we selected the catalytic data collected during the same periods between different gold-iron samples. The current results shown in Figure 5 justifies the optimized $\mathrm{pH}$ value is 11.2 for the hydrated iron oxide support, and thus the catalytic reactivity can be enhanced by tuning the precipitation $\mathrm{pH}$ values in the synthesis of $\mathrm{Fe} \_\mathrm{OH}$ supports. 
For gold on dehydrated iron oxide support, the related $\mathrm{CO}$ oxidation transient profiles are shown in Figure 5b. Here, we need to control the $\mathrm{CO}$ conversion at the modest level and select the $\mathrm{pH}$ value of 8.2 for the preparation of initial Fe_OH. This can effectively avoid the too small differences on the reactivity of $\mathrm{CO}$ oxidation when we investigate the effect of calcination temperature towards the $\mathrm{Fe} \_\mathrm{O}$ support. Clearly, $\mathrm{Au} / \mathrm{Fe} \_\mathrm{O} \_300$ was superior to $\mathrm{Au} / \mathrm{Fe} \_\mathrm{O} \_200$, displaying distinct lower $T_{90}\left(20^{\circ} \mathrm{C}\right.$ vs. $\left.85^{\circ} \mathrm{C}\right)$. Au/Fe_O_400 was almost identical to Au/Fe_O_300, while the reactivity of $\mathrm{Au} / \mathrm{Fe} \_\mathrm{O} \_500$ and $\mathrm{Au} / \mathrm{Fe} \_\mathrm{O} \_600$ dropped quickly with higher $\mathrm{T}_{90}$ of $35^{\circ} \mathrm{C}$ and $103{ }^{\circ} \mathrm{C}$, respectively. The long-term "steady-state" experiments in Figure 5d verify a similar trend for Au/Fe_O series. At a constant temperature of $30^{\circ} \mathrm{C}$, the stabilized CO conversions after $6-10 \mathrm{~h}$ on stream were $85 \%, 70 \%$, $40 \%, 32 \%$ and $20 \%$ for the Fe_O calcination temperature of $300,400,500,600$ and $200{ }^{\circ} \mathrm{C}$, respectively. All of the above demonstrate the following sequence of catalytic reactivity on $\mathrm{Au} / \mathrm{Fe} \_\mathrm{O}$ for the $\mathrm{CO}$ oxidation reaction: Au/Fe_O_300 $>$ Au/Fe_O_400 > Au/Fe_O_500 > Au/Fe_O_600 > Au/Fe_O_200. Previously, air-calcination at $400{ }^{\circ} \mathrm{C}$ was chosen to obtain the Fe_O support [28] which is also the optimized parameter according to our present work.
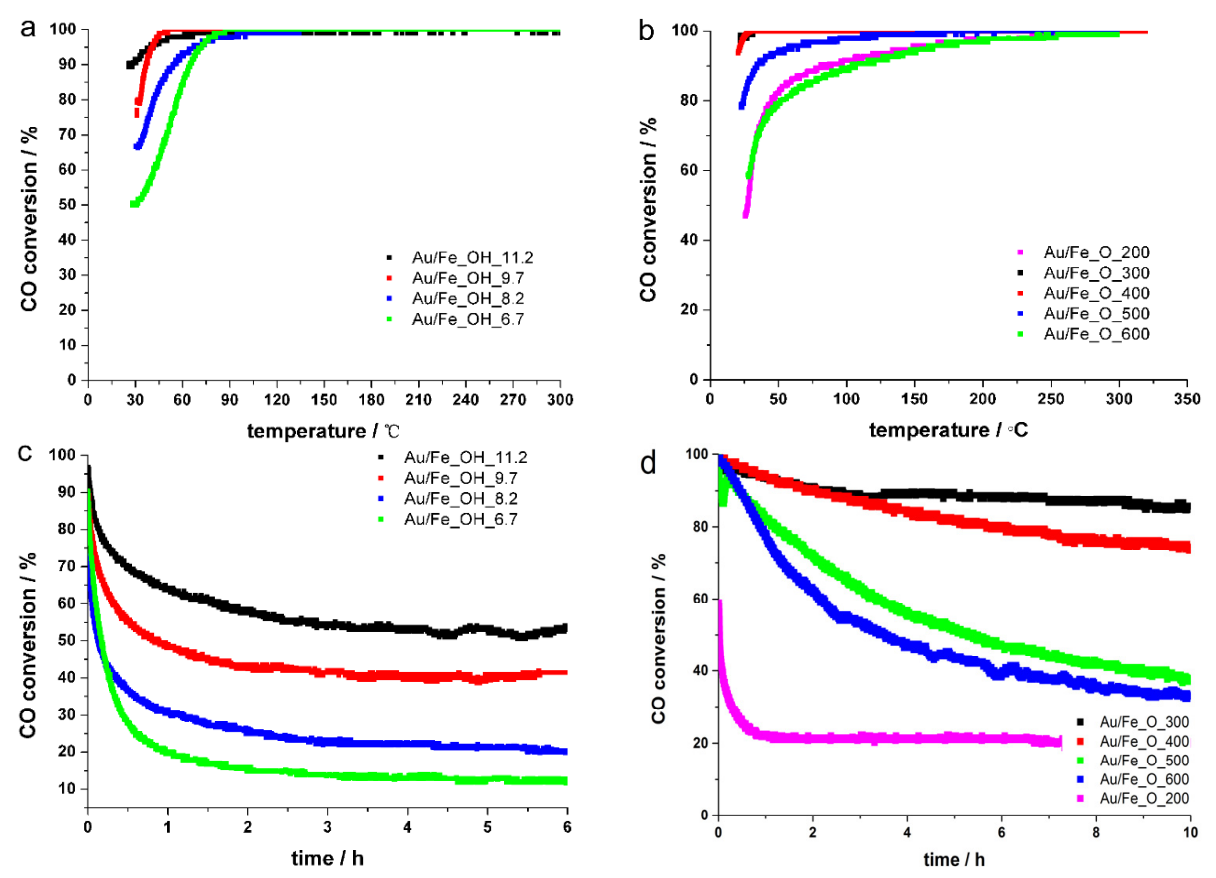

Figure 5. $\mathrm{CO}$ conversions of fresh $\mathrm{Au} / \mathrm{FeO}_{x}$ catalysts for the low-temperature $\mathrm{CO}$ oxidation reaction: (a) $\mathrm{Au} / \mathrm{Fe} \_\mathrm{OH}$, transient; (b) $\mathrm{Au} / \mathrm{Fe} \_\mathrm{O}$, transient; (c) $\mathrm{Au} / \mathrm{Fe} \_\mathrm{OH}$, stability at $30{ }^{\circ} \mathrm{C}$; and (d) $\mathrm{Au} / \mathrm{Fe} \_\mathrm{O}$, stability at $30{ }^{\circ} \mathrm{C}$. Reaction conditions: $1 \% \mathrm{CO} / 20 \% \mathrm{O}_{2} / 79 \% \mathrm{~N}_{2}, 80,000 \mathrm{~mL} \cdot \mathrm{h}^{-1} \cdot \mathrm{g}_{\text {cat }}{ }^{-1}$.

To correlate the catalytic reactivity of $\mathrm{CO}$ oxidation with the structure of gold-iron oxide, we carried out the $\mathrm{H}_{2}$-TPR tests on both fresh $\mathrm{Au} / \mathrm{Fe} \_\mathrm{OH}$ or $\mathrm{Au} / \mathrm{Fe} \_\mathrm{O}$ catalysts and the corresponding $\mathrm{Fe} \_\mathrm{OH}$ or $\mathrm{Fe} \_\mathrm{O}$ supports. For the $\mathrm{Au} / \mathrm{Fe} \_\mathrm{OH}$ series, the reduction of $\mathrm{Fe} \_\mathrm{OH}$ supports (Figure 6a) can be divided into two parts. The low-temperature reduction peaks between $180-220{ }^{\circ} \mathrm{C}$ and 350-400 ${ }^{\circ} \mathrm{C}$ can be attributed to the transformation of $\mathrm{Fe} \_\mathrm{OH} \rightarrow \mathrm{Fe}_{3} \mathrm{O}_{4}$ (first $\mathrm{Fe} \_\mathrm{OH} \rightarrow \mathrm{Fe}_{2} \mathrm{O}_{3}$ and then $\mathrm{Fe}_{2} \mathrm{O}_{3} \rightarrow \mathrm{Fe}_{3} \mathrm{O}_{4}$ ) [29], and the hydrogen consumption amount as shown in Table 2 clearly decreased from Fe_OH_6.7 to Fe_OH_11.2, probably due to less surface hydroxyls for the high precipitating pH value. The onset of high-temperature reduction peak, assigned to the conversion of $\mathrm{Fe}_{3} \mathrm{O}_{4} \rightarrow \mathrm{FeO}$ or Fe [29], was located at $350-400{ }^{\circ} \mathrm{C}$.

By the introduction of gold, Figure $6 \mathrm{~b}$ exhibits that the reduction of $\mathrm{Fe}_{3} \mathrm{O}_{4} \rightarrow \mathrm{FeO}$ or Fe was almost maintained. However, the reduction of $\mathrm{Fe}_{-} \mathrm{OH} \rightarrow \mathrm{Fe}_{3} \mathrm{O}_{4}$ was significantly shifted to lower temperature range of $30-230{ }^{\circ} \mathrm{C}$, and included a broad peak around $30-180{ }^{\circ} \mathrm{C}\left(\mathrm{Fe} \_\mathrm{OH} \rightarrow \mathrm{Fe}_{2} \mathrm{O}_{3}\right)$ and a sharp 
reduction centered at $195-214{ }^{\circ} \mathrm{C}\left(\mathrm{Fe}_{2} \mathrm{O}_{3} \rightarrow \mathrm{Fe}_{3} \mathrm{O}_{4}\right)$. This shift originated from the Au activation [30], or the strong interaction between gold and iron oxide support delivered by the structure of $\mathrm{Au}-\mathrm{OH}-\mathrm{Fe}$ or $\mathrm{Au}-\mathrm{O}-\mathrm{Fe}$ [31]. It can also be seen from Figure $6 \mathrm{~b}$ that the transformation of $\mathrm{Fe}-\mathrm{OH} \rightarrow \mathrm{Fe}_{2} \mathrm{O}_{3}(\mathrm{Au}-\mathrm{OH}-\mathrm{Fe})$ was kept the same, while the conversion of $\mathrm{Fe}_{2} \mathrm{O}_{3} \rightarrow \mathrm{Fe}_{3} \mathrm{O}_{4}(\mathrm{Au}-\mathrm{O}-\mathrm{Fe})$ was distinctly promoted with the increasing $\mathrm{pH}$ value in $\mathrm{Fe} \_\mathrm{OH}$ synthesis. This reveals a much stronger $\mathrm{Au}-\mathrm{O}-\mathrm{Fe}$ interaction in $\mathrm{Au} / \mathrm{Fe} \_\mathrm{OH} \_11.2$ than in $\mathrm{Au} / \mathrm{Fe} \_\mathrm{OH} \_6.7$, which could account for its better catalytic performance on the $\mathrm{CO}$ oxidation reaction.

Similarly, for the $\mathrm{Au} / \mathrm{Fe} \_\mathrm{O}$ series, the reduction of Fe_O supports (Figure $6 \mathrm{c}$ ) can be divided into two parts. The low-temperature reduction peaks between $200-300{ }^{\circ} \mathrm{C}$ and $350-400{ }^{\circ} \mathrm{C}$ can be attributed to the transformation of $\mathrm{Fe}_{-} \mathrm{O}\left(\right.$ or $\left.\mathrm{Fe}_{2} \mathrm{O}_{3}\right) \rightarrow \mathrm{Fe}_{3} \mathrm{O}_{4}$ [30,32], while the onset of high-temperature reduction peak, assigned to the conversion of $\mathrm{Fe}_{3} \mathrm{O}_{4} \rightarrow \mathrm{FeO}$ or Fe [32], was located at 350-400 ${ }^{\circ} \mathrm{C}$. Again, by the gold doping, Figure 6d exhibits that the reduction of $\mathrm{Fe}_{3} \mathrm{O}_{4} \rightarrow \mathrm{FeO}$ or Fe was kept the same, but the reduction of $\mathrm{Fe}_{2} \mathrm{O}_{3} \rightarrow \mathrm{Fe}_{3} \mathrm{O}_{4}$ was obviously shifted to lower temperatures below $270{ }^{\circ} \mathrm{C}$, possibly due to the presence of Au-O-Fe interaction [31]. This reduction temperature was increased with the calcination temperature of iron oxide support from 200 to $600^{\circ} \mathrm{C}$. The corresponding hydrogen consumption amount (Table 2) was raised from $\mathrm{Au} / \mathrm{Fe} \_200$ to $\mathrm{Au} / \mathrm{Fe} \_400$ and remained constant if the calcination temperature was further higher $\left(400-600{ }^{\circ} \mathrm{C}\right)$. It hints that the strong interaction of $\mathrm{Au}-\mathrm{O}-\mathrm{Fe}$ reached a spike at $\mathrm{Au} / \mathrm{Fe} \_400$. Besides, a minor peak below $170{ }^{\circ} \mathrm{C}$ can be identified for the transformation of $\mathrm{Fe} \_\mathrm{OH} \rightarrow \mathrm{Fe}_{2} \mathrm{O}_{3}$ for $\mathrm{Au} / \mathrm{Fe} \_200, \mathrm{Au} / \mathrm{Fe} \_300$ and $\mathrm{Au} / \mathrm{Fe} \_400$, while it disappeared for $\mathrm{Au} / \mathrm{Fe} \_500$ and $\mathrm{Au} / \mathrm{Fe} \_600$ since the higher calcination temperature on Fe_O can effectively remove the surface hydroxyls.
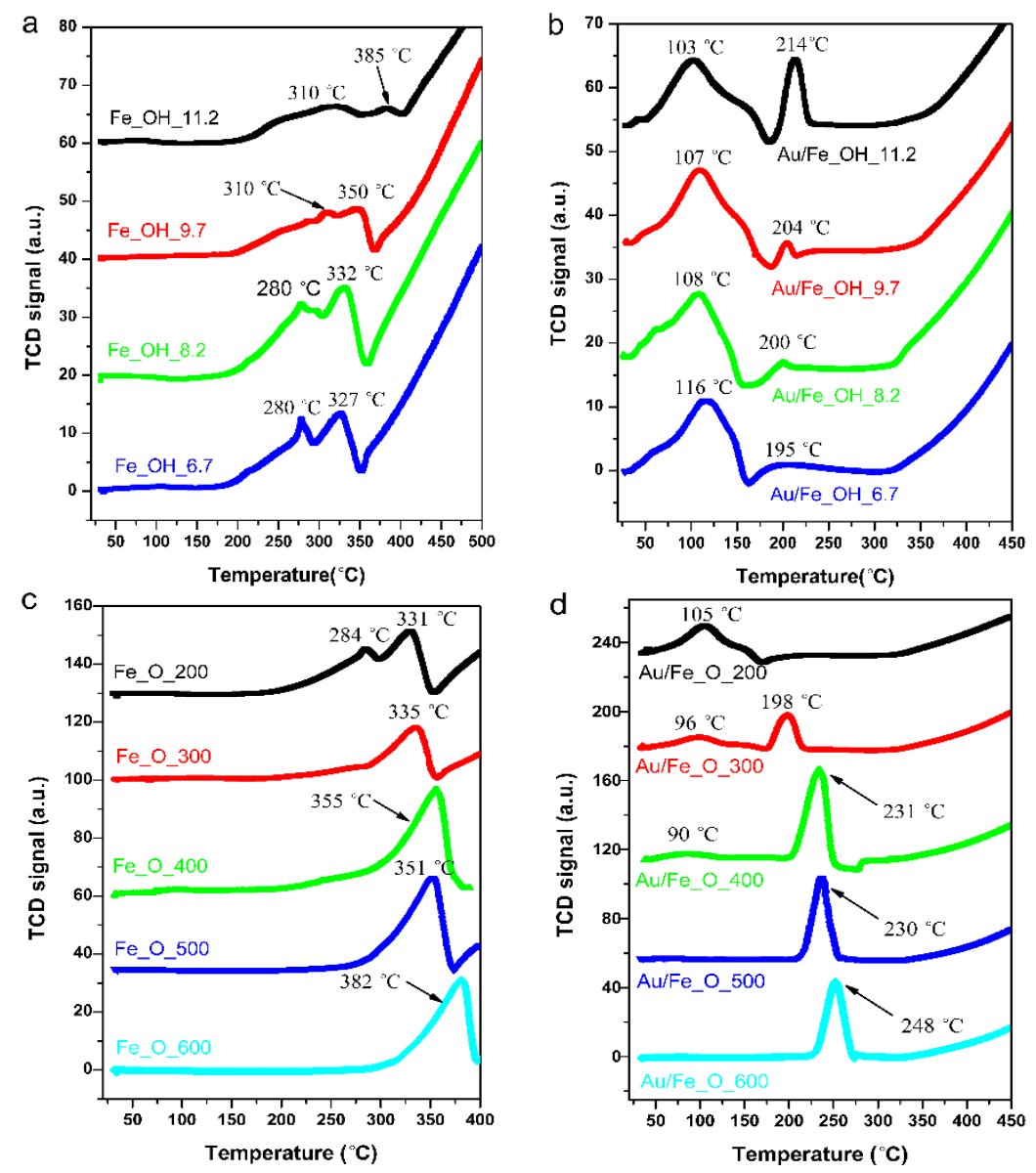

Figure 6. $\mathrm{H}_{2}$-TPR profiles of fresh $\mathrm{Au} / \mathrm{FeO}_{x}$ catalysts: (a) $\mathrm{Fe} \_\mathrm{OH}$; (b) $\mathrm{Au} / \mathrm{Fe} \_\mathrm{OH}$; (c) $\mathrm{Fe} \_\mathrm{O}$; and (d) $\mathrm{Au} / \mathrm{Fe} \_\mathrm{O}$. 
Table 2. Hydrogen consumption $\left(\mathrm{H}_{2}\right.$-consump.) of gold catalysts.

\begin{tabular}{|c|c|c|c|}
\hline Sample & Reduction Peak $\left({ }^{\circ} \mathrm{C}\right)$ & $\begin{array}{c}\text { Experimental } \mathrm{H}_{2} \text {-consump. } \\
\left(\mu \mathrm{mol} \cdot \mathrm{g}^{-1}\right)\end{array}$ & $\begin{array}{c}\text { Theoretical } \mathrm{H}_{2} \text {-consump. } \\
\left(\mu \mathrm{mol} \cdot \mathrm{g}^{-1}\right)\end{array}$ \\
\hline DP_Au/Fe_OH_11.2 & $102{ }^{\circ} \mathrm{C}, 214^{\circ} \mathrm{C}$ & 627 & 1300 \\
\hline DP_Au/Fe_OH_9.7 & $107^{\circ} \mathrm{C}, 204^{\circ} \mathrm{C}$ & 549 & 1300 \\
\hline DP_Au/Fe_OH_8.2 & $108^{\circ} \mathrm{C}, 200^{\circ} \mathrm{C}$ & 486 & 1300 \\
\hline DP_Au/Fe_OH_6.7 & $116^{\circ} \mathrm{C}, 195^{\circ} \mathrm{C}$ & 452 & 1300 \\
\hline DP_Au/Fe_O_200 & $105^{\circ} \mathrm{C}$ & 723 & 1510 \\
\hline DP_Au/Fe_O_300 & $96^{\circ} \mathrm{C}, 198^{\circ} \mathrm{C}$ & 778 & 1510 \\
\hline DP_Au/Fe_O_400 & $90{ }^{\circ} \mathrm{C}, 231^{\circ} \mathrm{C}$ & 1438 & 1510 \\
\hline DP_Au/Fe_O_500 & $230^{\circ} \mathrm{C}$ & 861 & 1510 \\
\hline DP_Au/Fe_O_600 & $248^{\circ} \mathrm{C}$ & 894 & 1510 \\
\hline
\end{tabular}

\subsection{Effect of Iron Oxide Support}

Previously, we utilized in-situ XAFS and XRD techniques to investigate the gold-iron oxide catalysts obtained by deposition-precipitation, and reported that metal-support interaction $(\mathrm{Au}-\mathrm{O}-\mathrm{Fe})$ is key factor to govern the $\mathrm{CO}$ oxidation reactivity of $\mathrm{Au} / \mathrm{FeO}_{x}$ [28]. In this work, we focused on the effect of iron oxide support and optimized the synthetic parameters for the $\mathrm{Fe} \_\mathrm{OH}$ and $\mathrm{Fe} \_\mathrm{O}$ preparation. To further study the reaction mechanism in Au-Fe-O system, we selected four typical samples to reveal the "structure-activity" relationship by different characterization methods. Two of them were gold on hydrated iron oxide $\left(\mathrm{Au} / \mathrm{Fe} \_\mathrm{OH}\right)$ with higher $\left(\mathrm{Au} / \mathrm{Fe} \_\mathrm{OH} \_11.2\right)$ and lower reactivity $\left(\mathrm{Au} / \mathrm{Fe} \_\mathrm{OH} \_6.7\right)$; another two were gold on dehydrated iron oxide $\left(\mathrm{Au} / \mathrm{Fe} \_\mathrm{O}\right)$ with higher $\left(\mathrm{Au} / \mathrm{Fe} \_\mathrm{O} \_300\right)$ and lower reactivity $\left(\mathrm{Au} / \mathrm{Fe} \_200\right)$.

In Section 2.1, using TEM/HRTEM, we found that $\sim 2 \mathrm{~nm}$ Au particles formed during the CO oxidation reaction, whether on Fe_OH (see Figure 4a,b) or on Fe_O (see Figure 4c,d). Since no such gold structure has been detected for the corresponding fresh samples, the transformation of Au species under the reaction conditions is crucial to the explanation for the different reactivity of the $\mathrm{Au} / \mathrm{FeO}$ catalysts. In Section 2.2, using $\mathrm{H}_{2}$-TPR, the strong interaction between metal $(\mathrm{Au})$ and support $\left(\mathrm{Fe} \_\mathrm{OH}\right.$ or Fe_O) has been demonstrated for the structural evolution of $\mathrm{Fe} \_\mathrm{OH} \rightarrow \mathrm{Fe}_{3} \mathrm{O}_{4}$ and $\mathrm{Fe}_{2} \mathrm{O}_{3} \rightarrow \mathrm{Fe}_{3} \mathrm{O}_{4}$, respectively. This could be the main reason for the origin of high activity for Au/Fe_OH_11.2 and $\mathrm{Au} / \mathrm{Fe} \_\mathrm{O} \_300$. However, the information on gold chemistry, especially oxidation state and short-range local structure around $\mathrm{Au}$, in the active $\mathrm{Au} / \mathrm{FeO}_{x}$ catalysts is still unknown.

XPS was conducted to determine the surface Au concentrations $\left(\mathrm{Au}_{\text {surf }}\right)$, and the related analysis results have been included in Table 1 . Most of the $\mathrm{Au}_{\text {surf }}$ values in the gold-iron oxide catalysts are close to the corresponding $\mathrm{Au}_{\text {bulk }}$ numbers, except for the used $\mathrm{Au} / \mathrm{Fe} \_\mathrm{OH} \_11.2(1.20$ at.\%) and $\mathrm{Au} / \mathrm{Fe} \_\mathrm{O} \_300(0.74$ at. \%) samples, in which their surfaces were obviously Au-richer compared with that in the corresponding fresh catalysts. Thus, the larger fraction of gold on the surface of iron oxide support during the catalytic tests can be attributed to the promotion in reactivity.

Furthermore, the XPS spectra of Fe 2p in Figure 7a,b clearly demonstrate that the oxidation state of iron was kept the same as $\mathrm{Fe}^{3+}[33,34]$ for all the measured samples before and after the $\mathrm{CO}$ oxidation reaction. This reveals that the oxidized iron species were very stable during the catalytic measurements, even with the introduction of reducing gas (CO). The XPS spectra of Au $4 \mathrm{f}$ in Figure 7c,d distinctly confirm that the oxidation state of gold was more ionic, exhibiting higher binding energies (also see Table 1), in all the fresh catalysts (Au/Fe_OH_11.2, Au/Fe_OH_6.7, Au/Fe_O_300, and Au/Fe_O_200) than after reaction. This indicates that $\mathrm{CO}$ reduced $\mathrm{Au}$ to form metallic species, which was in good agreement with the TEM/HRTEM results. 

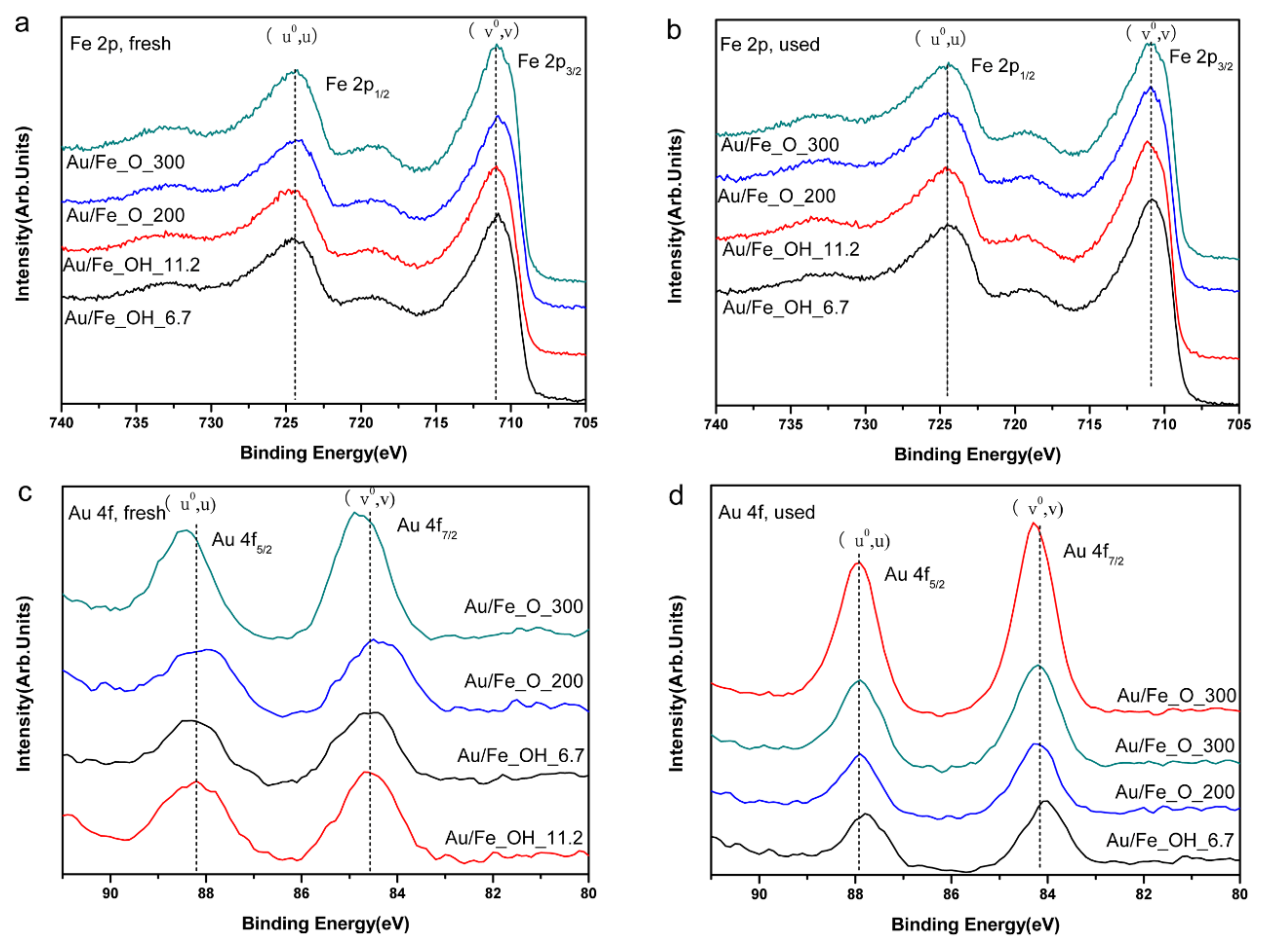

Figure 7. XPS spectra of $\mathrm{Au} / \mathrm{FeO}_{x}$ catalysts: (a) Fe 2p, fresh; (b) Fe 2p, used; (c) Au 4f, fresh; and (d) Au 4f, used.

Therefore, XAFS technique was used to investigate the electronic structure in the gold-iron oxide catalysts before and after the $\mathrm{CO}$ oxidation reaction. The related white line in the XANES profiles distinctly changes with the structural evolution on $\mathrm{Au}\left(\mathrm{Au}^{0}\right.$ and $\left.\mathrm{Au}^{\delta+}\right)$ [28]. Compared to XPS, XANES test can be conducted under milder ambient conditions and exclude the effect of ultra-high vacuum level. Thus, we selected the XANES approach to identify the oxidation states of gold in this work.

The $\mathrm{Au}$ L3-edge XANES spectrum of $\mathrm{Au} / \mathrm{FeO}_{x}$ catalysts is compared with that of $\mathrm{Au}$ foil in Figure 8. For the fresh samples (see Figure 8a), the Au L3 edges were obviously shifted to higher energies, if compared to that of $\mathrm{Au}^{\circ}$ standard, confirming their $\mathrm{Au}^{\delta+}$ nature. Meanwhile, strong white line was clearly observed, which verifies that the ionic gold species were dominant in the fresh catalysts $[35,36]$. Interestingly, according to the height of white line in Figure 8a, the oxidation state of $\mathrm{Au}$ in each gold-iron oxide sample follows this sequence: $\mathrm{Au} / \mathrm{Fe} \_\mathrm{OH} \_11.2>$ $\mathrm{Au} / \mathrm{Fe} \_\mathrm{O} \_300>\mathrm{Au} / \mathrm{Fe} \_\mathrm{OH} \_6.7>\mathrm{Au} / \mathrm{Fe} \_\mathrm{O} \_200$. This was well consistent with the catalytic reactivity order: Au/Fe_OH_11.2 > Au/Fe_OH_6.7 and Au/Fe_O_300 > Au/Fe_O_200.
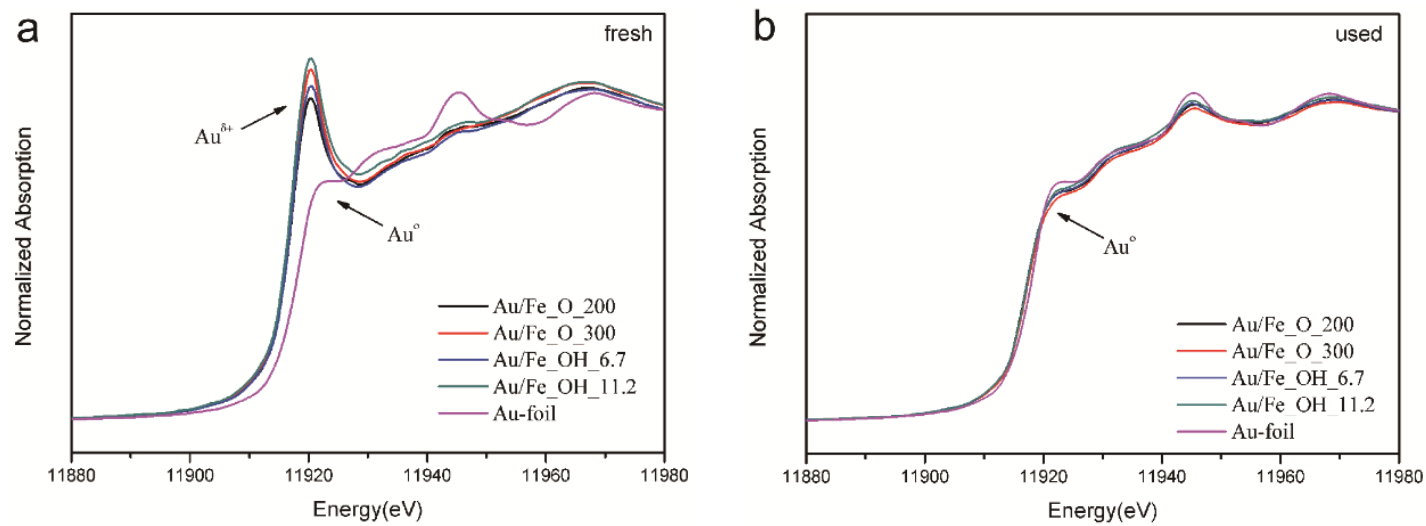

Figure 8. XANES profiles of $\mathrm{Au} \mathrm{L} 3$ edge for $\mathrm{Au} / \mathrm{FeO}_{x}$ catalysts: (a) fresh and (b) used. 
However, after the reaction, gold in all the used $\mathrm{Au} / \mathrm{FeO}_{x}$ catalysts was reduced to almost pure $\mathrm{Au}^{\circ}$ species based on the XANES profiles in Figure 8b. This was in good agreement with the TEM/HRTEM and XPS data. Therefore, the different Au oxidation states in the fresh samples were crucial for the significant differences in reactivity between gold supported on various Fe_OH and Fe_O matrices.

\section{Experimental Section}

\subsection{Catalyst Preparation}

\subsubsection{Preparation of Fe_OH with Different pH Values [8]}

$\mathrm{Na}_{2} \mathrm{CO}_{3} \cdot 10 \mathrm{H}_{2} \mathrm{O}(99.9 \%)$ and $\mathrm{Fe}\left(\mathrm{NO}_{3}\right)_{3} \cdot 6 \mathrm{H}_{2} \mathrm{O}(99 \%)$ were purchased from Tianjin Kermal Chemical Reagent Factory (Tianjin, China). Typically, $0.25 \mathrm{~mol} \cdot \mathrm{L}^{-1} \mathrm{Na}_{2} \mathrm{CO}_{3}$ aqueous solution was added drop wisely to $200 \mathrm{~mL}$ of $0.1 \mathrm{~mol} \cdot \mathrm{L}^{-1} \mathrm{Fe}\left(\mathrm{NO}_{3}\right)_{3}$ aqueous solution under stirring at $80{ }^{\circ} \mathrm{C}$ until specific $\mathrm{pH}$ value $(6.7,8.2,9.7$, and 11.2$)$ was reached. The stock solution was aged under stirring at $80^{\circ} \mathrm{C}$ for another $1 \mathrm{~h}$, and then the as-formed precipitate was collected by filtration. The solid product was washed with deionized (DI) water at $80^{\circ} \mathrm{C}$ several times until the final $\mathrm{pH}$ was neutral. This powder was dried at $120^{\circ} \mathrm{C}$ in still air for $12 \mathrm{~h}$ to generate the Fe_OH supports, marked as Fe_OH_6.7, Fe_OH_8.2, Fe_OH_9.7 and Fe_OH_11.2.

\subsubsection{Preparation of Fe_O with Different Calcination Temperatures}

The Fe_OH_8.2 supports were ground into fine powders, and calcined at different temperatures $\left(200,300,400,500\right.$ and $600{ }^{\circ} \mathrm{C}$ ) for $2 \mathrm{~h}\left(\right.$ rate of $\left.5^{\circ} \mathrm{C} \cdot \mathrm{min}^{-1}\right)$ to generate the $\mathrm{Fe} \_\mathrm{O}$ supports, marked as Fe_O_200, Fe_O_300, Fe_O_400, Fe_O_500, and Fe_O_600.

\subsubsection{Deposition of Gold onto Fe_OH or Fe_O}

For the sequential deposition-precipitation process, $0.5 \mathrm{~g}$ Fe_OH or Fe_O support powders were suspended in $23 \mathrm{~mL}$ Millipore water $\left(18.25 \mathrm{M} \Omega\right.$ ) under stirring. Then, $2 \mathrm{~mL}$ of $0.0125 \mathrm{~mol} \cdot \mathrm{L}^{-1} \mathrm{HAuCl}_{4}$ aqueous solution was added to the above solution at $60^{\circ} \mathrm{C}$. After $30 \mathrm{~min}, 25 \mathrm{~mL}$ of aqueous solution containing $0.5 \mathrm{~g}$ of urea was quickly added into the stock solution. Thereafter, the stock solution was heated up to $80^{\circ} \mathrm{C}$ under vigorously stirring and the temperature was kept for $3 \mathrm{~h}$. The $\mathrm{pH}$ value of this solution was raised from 4.0 to 8.6 , resulting in the full decomposition of urea. The stock solution was further aged at room temperature for another $20 \mathrm{~h}$. The as-prepared product was collected by filtration, and washed with Millipore water at $60^{\circ} \mathrm{C}$ several times until the final $\mathrm{pH}$ value was neutral. After being dried at $60^{\circ} \mathrm{C}$ overnight in still air, the fresh $\mathrm{Au} / \mathrm{Fe} \_\mathrm{OH}$ and $\mathrm{Au} / \mathrm{Fe} \_\mathrm{O}$ catalysts were obtained. The designed gold concentration in each sample was fixed at $1 \mathrm{wt}$. \%, calculated as $\mathrm{Au} / \mathrm{Fe}(\mathrm{OH})_{3}$, or 0.54 at. \%, calculated as $\mathrm{Au} /(\mathrm{Au}+\mathrm{Fe}) . \mathrm{HAuCl}_{4} \cdot 4 \mathrm{H}_{2} \mathrm{O}(99.9 \%)$ were purchased from National Chemicals (Shanghai, China).

\subsection{Characterization}

The actual gold loadings of catalysts were determined by inductively coupled plasma atomic emission spectroscopy (ICP-AES) on an IRIS Intrepid II XSP instrument (Thermo Electron Corporation, Waitham, MA, USA).

The nitrogen adsorption-desorption measurements were performed on a NOVA 4200e instrument (Quantachrome Corporation, Boynton Beach, FL, USA) at $77 \mathrm{~K}$. The samples were outgassed at $120^{\circ} \mathrm{C}$ for $12 \mathrm{~h}$ under vacuum prior to measurements. The BET specific surface areas $\left(\mathrm{S}_{\mathrm{BET}}\right)$ were calculated from the adsorption data in the relative pressure range between 0.05 and 0.30 .

X-ray photoelectron spectroscopy (XPS) analysis was performed on an Axis Ultra XPS spectrometer (Kratos, UK) with $225 \mathrm{~W}$ of $\mathrm{Al} K_{\alpha}$ radiation. The $\mathrm{C} 1 \mathrm{~s}$ line at $284.8 \mathrm{eV}$ was used to 
calibrate the binding energies. The surface gold concentrations $\left(\mathrm{Au}_{\text {surf }}\right.$ in at. \%) were determined by integrating the areas of $\mathrm{Au} 4 \mathrm{f}$ and $\mathrm{Fe} 2 \mathrm{p}$ peaks.

X-ray Diffraction (XRD) was operated on a Bruker D8 Advance diffractometer (Bruker-AXS; Karlsruhe, Germany, $40 \mathrm{kV}, 40 \mathrm{~mA})$, using $\mathrm{Cu} K_{\alpha}$ radiation $(\lambda=0.15406 \mathrm{~nm})$. The powder catalyst after grinding was placed inside a quartz-glass sample holder before test.

X-ray absorption near edge structure (XANES) spectra at Au K-edge $\left(E_{0}=11,919 \mathrm{eV}\right)$ were performed at BL14W1 beam line of Shanghai Synchrotron Radiation Facility (SSRF) operated at $3.5 \mathrm{GeV}$ under "top-up" mode with a constant current of $240 \mathrm{~mA}$. The XAFS data were recorded under fluorescence mode with 32-element Ge solid-state detector. The energy was calibrated accordingly to the absorption edge of pure Au foil. Athena codes were used to extract the data. The experimental absorption coefficients as function of energies $\mu(E)$ were processed by background subtraction and normalization procedures, and reported as "normalized absorption". Based on the normalized XANES profiles, the oxidation state of $\mathrm{Au}$ in each catalyst can be determined.

Transmission electron microscopy (TEM) was conducted on a field emission TEM (JEOL 2100F, Tokyo, Japan) machine equipped with a $2 \mathrm{k} \times 2 \mathrm{k}$ CCD camera at $200 \mathrm{kV}$. High-resolution TEM (HRTEM) and the related energy dispersive X-ray analysis (EDAX) was carried out on a Philips Tecnai $\mathrm{G}^{2}$ F20 instrument (FEI Company, Hillsboro, TX, USA) at $200 \mathrm{kV}$. All the tested sample powders were suspended in ethanol before deposition on an ultra-thin carbon film-coated copper grid.

Temperature-programmed reduction by hydrogen $\left(\mathrm{H}_{2}-\mathrm{TPR}\right)$ was carried out in a Builder PCSA-1000 instrument (Beijing, China) equipped with a thermal conductivity detector (TCD) to detect $\mathrm{H}_{2}$ consumption. The sieved catalysts $(20-40 \mathrm{mesh}, 30 \mathrm{mg})$ were heated $\left(5^{\circ} \mathrm{C} \cdot \mathrm{min}^{-1}\right)$ from room temperature to $400{ }^{\circ} \mathrm{C}$ in a $20 \% \mathrm{H}_{2} / \mathrm{Ar}\left(30 \mathrm{~mL} \cdot \mathrm{min}^{-1}\right)$ gas mixture. Before the measurements were taken, the fresh samples were pretreated in pure $\mathrm{O}_{2}$ at $300^{\circ} \mathrm{C}$ for $30 \mathrm{~min}$.

\subsection{Catalytic Test}

$\mathrm{CO}$ oxidation activities of $\mathrm{Au} / \mathrm{FeO}_{x}$ catalysts were evaluated in a plug flow reactor using $50 \mathrm{mg}$ of sieved (20-40 mesh) catalyst in a gas mixture of 1 vol. \% CO, 20 vol. $\% \mathrm{O}_{2}$, and 79 vol. \% $\mathrm{N}_{2}(99.997 \%$ purity from Deyang Gas Company, Jinan, China), at a flow rate of $67 \mathrm{~mL} \cdot \mathrm{min}^{-1}$, corresponding to a space velocity of $80,000 \mathrm{~mL} \cdot \mathrm{h}^{-1} \cdot \mathrm{g}_{\mathrm{cat}}{ }^{-1}$. Prior to the test, the catalysts were pretreated in air at $300^{\circ} \mathrm{C}$ for $30 \mathrm{~min}$ for activation. After the catalysts cooled down to room temperature under a flow of pure $\mathrm{N}_{2}$ gas, reactant gases were passed through the reactor. The catalytic tests in "transient" mode were carried out in the reactant atmosphere by ramping the catalyst temperature $\left(5^{\circ} \mathrm{C} \cdot \mathrm{min}^{-1}\right)$ from room temperature to $300^{\circ} \mathrm{C}$. The outlet gas compositions of $\mathrm{CO}$ and $\mathrm{CO}_{2}$ were monitored online by a non-dispersive IR spectroscopy (Gasboard-3500, Wuhan Sifang Company, Wuhan, China). A typical "steady-state" experiment $\left(30^{\circ} \mathrm{C}\right)$ was conducted in the same gas-mixture at $30^{\circ} \mathrm{C}$ for more than $10 \mathrm{~h}$.

\section{Conclusions}

In summary, we have prepared two series of gold-iron oxide catalysts, $\mathrm{Au} / \mathrm{Fe} \_\mathrm{OH}$ and $\mathrm{Au} / \mathrm{Fe} \_\mathrm{O}$, by depositing Au onto hydrated and dehydrated supports, and further investigated their catalytic performance for the low-temperature $\mathrm{CO}$ oxidation reaction. Based on the related activity test results, we have demonstrated that the precipitating $\mathrm{pH}$ value and the calcination temperature for the iron oxide support are two key factors governing the gold catalysis. By multiple characterization techniques, including XRD, $\mathrm{N}_{2}$ adsorption, TEM/HRTEM, XPS, XAFS and $\mathrm{H}_{2}$-TPR, we have found that the metallic $\mathrm{Au}$ strongly interacting with the oxide support is the active site for $\mathrm{CO}$ oxidation.

Acknowledgments: Financial support from the National Science Foundation of China (NSFC) (grant Nos. 21373259 and 21301107), the Hundred Talents project of the Chinese Academy of Sciences, the Strategic Priority Research Program of the Chinese Academy of Sciences (grant No. XDA09030102), fundamental research funding of Shandong University (grant No. 2014JC005), the Taishan Scholar project of Shandong Province (China), and open funding from Beijing National Laboratory for Molecular Science and Key Laboratory of Interfacial Physics and Technology, Chinese Academy of Sciences are greatly appreciated. 
Author Contributions: C.-J.J. and R.S. conceived and designed the project. H.-Z.C. and Y.G. performed the catalyst preparation, characterization and catalytic tests. X.W. conducted the XAFS and HRTEM measurements. R.S., C.-J.J. and H.-Z.C. wrote the manuscript.

Conflicts of Interest: The authors declare no conflict of interest.

\section{References}

1. Haruta, M.; Tsubota, S.; Kobayashi, T.; Kageyama, H.; Genet, M.J.; Delmon, B. Low-temperature oxidation of $\mathrm{CO}$ over gold supported on $\mathrm{TiO}_{2}, \alpha-\mathrm{Fe}_{2} \mathrm{O}_{3}$, and $\mathrm{Co}_{3} \mathrm{O}_{4}$. J. Catal. 1993, 144, 175-192. [CrossRef]

2. Haruta, M.; Kobayashi, T.; Sano, H.; Yamada, N. Novel gold catalysts for the oxidation of carbon monoxide at a temperature far below $0{ }^{\circ} \mathrm{C}$. Chem. Lett. 1987, 16, 405-408. [CrossRef]

3. Hashmi, A.S.K.; Hutchings, G.J. Gold catalysis. Angew. Chem. Int. Ed. 2006, 45, 7896-7936. [CrossRef] [PubMed]

4. Valden, M.; Lai, X.; Goodman, D.W. Onset of catalytic activity of gold clusters on titania with the appearance of nonmetallic properties. Science 1998, 281, 1647-1650. [CrossRef] [PubMed]

5. Widmann, D.; Leppelt, R.; Behm, R.J. Activation of an $\mathrm{Au} / \mathrm{CeO}_{2}$ catalyst for the $\mathrm{CO}$ oxidation reaction by surface oxygen removal/oxygen vacancy formation. J. Catal. 2007, 251, 437-442. [CrossRef]

6. Camellone, M.F.; Fabris, S. Reaction mechanisms for the $\mathrm{CO}$ oxidation on $\mathrm{Au} / \mathrm{CeO}_{2}$ catalysts: Activity of substitutional $\mathrm{Au}^{3+} / \mathrm{Au}^{+}$cations and deactivation of supported $\mathrm{Au}^{+}$Adatoms. J. Am. Chem. Soc. 2009, 131, 10473-10483. [CrossRef] [PubMed]

7. Haruta, M.; Yamada, N.; Kobayashi, T.; Iijima, S. Gold catalysts prepared by coprecipitation for low-temperature oxidation of hydrogen and of carbon monoxide. J. Catal. 1989, 115, 301-309. [CrossRef]

8. Herzing, A.A.; Kiely, C.J.; Carley, A.F.; Landon, P.; Hutchings, G.J. Identification of active gold nanoclusters on iron oxide supports for CO oxidation. Science 2008, 321, 1331-1335. [CrossRef] [PubMed]

9. Daniells, S.T.; Overweg, A.R.; Makkee, M.; Moulijn, J.A. The mechanism of low-temperature CO oxidation with $\mathrm{Au} / \mathrm{Fe}_{2} \mathrm{O}_{3}$ catalysts: A combined Mössbauer, FT-IR, and TAP reactor study. J. Catal. 2005, 230, 52-65. [CrossRef]

10. Hutchings, G.J.; Hall, M.S.; Carley, A.F.; Landon, P.; Solsona, B.E.; Kiely, C.J.; Herzing, A.; Makkee, M.; Moulijn, J.A.; Overweg, A.; et al. Role of gold cations in the oxidation of carbon monoxide catalyzed by iron oxide-supported gold. J. Catal. 2006, 242, 71-81. [CrossRef]

11. Li, L.; Wang, A.-Q.; Qiao, B.-T.; Lin, J.; Huang, Y.-Q.; Wang, X.-D.; Zhang, T. Origin of the high activity of $\mathrm{Au} / \mathrm{FeO}_{x}$ for low-temperature CO oxidation: Direct evidence for a redox mechanism. J. Catal. 2013, 299, 90-100. [CrossRef]

12. Liu, Y.; Jia, C.-J.; Yamasaki, J.; Terasaki, O.; Schuth, F. Highly active iron oxide supported gold catalysts for CO oxidation: How small must the gold nanoparticles be? Angew. Chem. Int. Ed. 2010, 49, 5771-5775. [CrossRef] [PubMed]

13. Zhong, Z.-Y.; Ho, J.; Teo, J.; Shen, S.-C.; Gedanken, A. Synthesis of porous $\alpha-\mathrm{Fe}_{2} \mathrm{O}_{3}$ nanorods and deposition of very small gold particles in the pores for catalytic oxidation of CO. Chem. Mater. 2007, 19, 4776-4782. [CrossRef]

14. Andreeva, D. Low temperature water gas shift over gold catalysts. Good Bull. 2002, 35, 82-88. [CrossRef]

15. Boccuzzi, F.; Chiorino, A.; Manzoli, M.; Andreeva, D.; Tabakova, T. FTIR study of the low-temperature water-gas shift reaction on $\mathrm{Au} / \mathrm{Fe}_{2} \mathrm{O}_{3}$ and $\mathrm{Au} / \mathrm{TiO}_{2}$ catalysts. J. Catal. 1999, 188, 176-185. [CrossRef]

16. Silberova, B.A.A.; Mul, G.; Makkee, M.; Moulijn, J.A. DRIFTS study of the water-gas shift reaction over $\mathrm{Au} / \mathrm{Fe}_{2} \mathrm{O}_{3}$. J. Catal. 2006, 243, 171-182.

17. Andreevaa, D.; Tabakovaa, T.; Idakieva, V.; Christova, P.; Giovanolib, R. Au/ $\alpha-\mathrm{Fe}_{2} \mathrm{O}_{3}$ catalyst for water-gas shift reaction prepared by deposition-precipitation. Appl. Catal. A 1998, 169, 9-14. [CrossRef]

18. Schubert, M.M.; Venugopal, A.; Kahlich, M.J.; Plzak, V.; Behm, R.J. Influence of $\mathrm{H}_{2} \mathrm{O}$ and $\mathrm{CO}_{2}$ on the selective $\mathrm{CO}$ oxidation in $\mathrm{H}_{2}$-rich gases over $\mathrm{Au} / \alpha-\mathrm{Fe}_{2} \mathrm{O}_{3}$. J. Catal. 2004, 222, 32-40. [CrossRef]

19. Shodiya, T.; Schmidt, O.; Peng, W.; Hotz, N. Novel nano-scale $\mathrm{Au} / \alpha-\mathrm{Fe}_{2} \mathrm{O}_{3}$ catalyst for the preferential oxidation of CO in biofuel reformate gas. J. Catal. 2013, 300, 63-69. [CrossRef]

20. Landon, P.; Ferguson, J.; Solsona, B.E.; Garcia, T.; Sayari, S.A.; Carley, A.F.; Herzing, A.A.; Kiely, C.J.; Makkee, M.; Moulijn, J.A.; et al. Selective oxidation of $\mathrm{CO}$ in the presence of $\mathrm{H}_{2}, \mathrm{H}_{2} \mathrm{O}$ and $\mathrm{CO}_{2}$ utilizing $\mathrm{Au} / \alpha-\mathrm{Fe}_{2} \mathrm{O}_{3}$ catalysts for use in fuel cells. J. Mater. Chem. 2006, 16, 199-208. [CrossRef] 
21. Ozaki, M.; Kratohvil, S.; Matijević, E. Formation of monodispersed spindle-type hematite particles. J. Colloid Interface Sci. 1984, 102, 146-151. [CrossRef]

22. Sugimoto, T.; Sakata, K. Preparation of monodisperse pseudocubic $\alpha-\mathrm{Fe}_{2} \mathrm{O}_{3}$ particles from condensed ferric hydroxide gel. J. Colloid Interface Sci. 1992, 152, 587-590. [CrossRef]

23. Jia, C.-J.; Sun, L.-D.; Yan, Z.-G.; You, L.-P.; Luo, F.; Han, X.-D.; Pang, Y.-C.; Zhang, Z.; Yan, C.-H. Single-crystalline iron oxide nanotubes. Angew. Chem. Int. Ed. 2005, 117, 4402-4407. [CrossRef]

24. Jia, C.-J.; Sun, L.-D.; Luo, F.; Han, X.-D.; Heyderman, L.J.; Yan, Z.-G.; Yan, C.-H.; Zheng, K.; Zhang, Z.; Takano, M.; et al. Large-scale synthesis of single-crystalline iron oxide magnetic nanorings. J. Am. Chem. Soc. 2008, 130, 16968-16977. [CrossRef] [PubMed]

25. Finch, R.M.; Hodge, N.A.; Hutchings, G.J.; Meagher, A.; Pankhurst, Q.A.; Siddiqui, M.R.H.; Wagnerc, F.E.; Whyman, R. Identification of active phases in Au-Fe catalysts for low-temperature CO oxidation. Phys. Chem. Chem. Phys. 1999, 1, 485-489. [CrossRef]

26. Qian, K.; Zhang, W.-H.; Sun, H.-X.; Fang, J.; He, B.; Ma, Y.-S.; Jiang, Z.-Q.; Wei, S.-Q.; Yang, J.-L.; Huang, W.-X. Hydroxyls-induced oxygen activation on "inert" Au nanoparticles for low-temperature CO oxidation. J. Catal. 2011, 277, 95-103. [CrossRef]

27. Hodge, N.A.; Kiely, C.J.; Whyman, R.; Siddiqui, M.R.H.; Hutchings, G.J.; Pankhurst, Q.A.; Wagner, F.E.; Rajaram, R.R.; Golunski, S.E. Microstructural comparison of calcined and uncalcined gold/iron-oxide catalysts for low-temperature CO oxidation. Catal. Today 2002, 72, 133-144. [CrossRef]

28. Guo, Y.; Gu, D.; Jin, Z.; Du, P.-P.; Si, R.; Tao, J.; Xu, W.-Q.; Huang, Y.-Y.; Senanayake, S.; Song, Q.-S.; et al. Uniform $2 \mathrm{~nm}$ gold nanoparticles supported on iron oxides as active catalysts for CO oxidation reaction: Structure-activity relationship. Nanoscale 2015, 7, 4920-4928. [CrossRef] [PubMed]

29. Venugopal1, A.; Scurrell, M.S. Low temperature reductive pretreatment of $\mathrm{Au} / \mathrm{Fe}_{2} \mathrm{O}_{3}$ catalysts, TPR/TPO studies and behaviour in the water-gas shift reaction. Appl. Catal. A 2004, 258, 241-249. [CrossRef]

30. Wang, D.-H.; Hao, Z.-P.; Cheng, D.-Y.; Shi, X.-C. Influence of the calcination temperature on the $\mathrm{Au} / \mathrm{FeO}_{x} / \mathrm{Al}_{2} \mathrm{O}_{3}$ catalyst. J. Chem. Technol. Biotechnol. 2006, 81, 1246-1251. [CrossRef]

31. Deng, W.-L.; Carpenter, C.; Yia, N.; Stephanopoulos, M.F. Comparison of the activity of $\mathrm{Au} / \mathrm{CeO}_{2}$ and $\mathrm{Au} / \mathrm{Fe}_{2} \mathrm{O}_{3}$ catalysts for the $\mathrm{CO}$ oxidation and the water-gas shift reactions. Top. Catal. 2007, 44, 199-208. [CrossRef]

32. Kadkhodayan, A.; Brenner, A. Temperature-programmed reduction and oxidation of metals supported on $\gamma$-alumina. J. Catal. 1989, 117, 311-321. [CrossRef]

33. Huang, J.; Dai, W.-L.; Fan, K.-N. Remarkable support crystal phase effect in $\mathrm{Au} / \mathrm{FeO}_{x}$ catalyzed oxidation of 1,4-butanediol to c-butyrolactone. J. Catal. 2009, 266, 228-235. [CrossRef]

34. Yamashita, T.; Hayes, P. Analysis of XPS spectra of $\mathrm{Fe}^{2+}$ and $\mathrm{Fe}^{3+}$ ions in oxide materials. Appl. Surf. Sci. 2008, 254, 2441-2449. [CrossRef]

35. Deng, W.-L.; Frenkel, A.I.; Si, R.; Flytzani-Stephanopoulos, M. Reaction-Relevant Gold Structures in the Low Temperature Water-Gas Shift Reaction on Au-CeO 2. J. Phys. Chem. C 2008, 112, 12834-12840. [CrossRef]

36. Zanella, R.; Giorgio, S.; Shin, C.H.; Henry, C.R.; Louis, C. Characterization and reactivity in CO oxidation of gold nanoparticles supported on $\mathrm{TiO}_{2}$ prepared by deposition-precipitation with $\mathrm{NaOH}$ and urea. J. Catal. 2004, 222, 357-367. [CrossRef]

(C) 2016 by the authors; licensee MDPI, Basel, Switzerland. This article is an open access article distributed under the terms and conditions of the Creative Commons by Attribution (CC-BY) license (http://creativecommons.org/licenses/by/4.0/). 